\title{
Impact of inclusive education on improving the quality of life of totally blind students
}

\author{
Viktoriya Klimentyeva ${ }^{1 *}$, Dmitry Klimentyev ${ }^{1}$, Svetlana Pashneva ${ }^{2}$, Anna Umerenkova $^{1}$, \\ and Dina Fedorova ${ }^{1}$ \\ ${ }^{1}$ Kursk State University, Language Theory and Foreign Language Teaching Chair, Kursk, Russia \\ ${ }^{2}$ Kursk State University, Translation and Intercultural Communnication Chair, Kursk, Russia
}

\begin{abstract}
The desire of contemporary society to improve the quality of life through the organization of wider access to education for people with disabilities raises several issues concerning the conditions for organizing inclusive education. In the article based on theoretical analysis and practical experience in implementing five-year research and educational project in cooperation with the Moscow City University, the hypothesis is substantiated that using specially developed didactic materials, individual training of applicants according to an adapted curriculum, and adaptive teaching methods, it is possible to ensure successful foreign language training of a foreign language teacher for blind and visually impaired adults enrolled in the inclusive education in an undergraduate program. The purpose of the study is to find the possibilities of teaching a foreign language to totally blind adults studying in an inclusive educational environment of a higher educational institution with the subsequent successful implementation of their professional activities. The scientific novelty of the research is seen in the development and testing of a model of methodically substantiated professionally-focused educational trajectory of foreign language education for totally blind adults studying at the university. Using classical research methods, such as the study of scientific literature and accumulated methodological experience, trial training, observation, and questionnaires, the researchers came to conclusions about the feasibility and productivity of the proposed approach to teaching English to blind students in an inclusive environment, contributing to a more effective professional training of people with disabilities, improving their self-esteem, better adaptation to life, as well as professional and personal advancement of all participants in the educational process.
\end{abstract}

Keywords: English language teaching, higher education, totally blind, inclusive educational environment.

\section{Introduction}

\footnotetext{
*Corresponding author: v klimentyeva@mail.ru
} 
According to the World Health Organization (WHO), about 2.2 billion people worldwide suffer from severe visual impairment or are totally blind [1]. The experience gained through cooperation with specialized educational institutions in Russia, in particular, with correctional classes for the visually impaired children at schools in Kursk and the Kursk Music College-boarding school for the blind, allows the conclusion that their graduates are guaranteed to acquire secondary and vocational education. However, they still experience significant challenges in personal, social, and professional adaptation. The UNESCO Salamanca Statement set the objective "to promote integration and involvement, and to combat exclusion" [2], ensuring true equal opportunities. One solution to this goal is seen in the implementation of inclusive education, whose success depends on several organizational and pedagogical conditions, including special methods, adapted content and curricula, modified assessment methods, and ensuring an accessible educational environment [3, 4].

Since 2016, Kursk State University has been implementing research and educational project on teaching English to blind and visually impaired students. The study was launched in cooperation with the Moscow City University. The goal of the project is to study the possibilities of teaching a foreign language to totally blind adults studying in inclusive education at a university with the subsequent successful implementation of their professional activities. The scientific novelty of the project consists in developing and testing a model of methodologically based professionally-focused educational trajectory of foreign language learning for totally blind adults studying at the university. As a hypothesis, it is suggested that based on specially developed learning materials and course content, preliminary individual training of prospective students, and adaptive teaching methods in the framework of inclusive education in an undergraduate program, it is possible to ensure successful professional and personal advancement of all students in the inclusive group.

The research objectives correspond to the stages of the scientific and educational project:

1) studying scientific literature and curricular practices;

2) developing didactic materials;

3) preparing future students for undergraduate studies;

4) training in an inclusive educational environment at the university;

5) conducting an analysis of the results obtained, and disseminating the gained experience.

\section{Methods}

The nature of the study determined the methods that ensured reliable results. These included studying scientific literature and accumulated methodological practices, as well as conducting trial training, observation, and questionnaire surveys.

\section{Results}

In the course of the study, the authors analyzed publications and didactic materials related to the methodology of teaching foreign languages to students with different educational needs. The problem of inclusion of blind and visually impaired people is widely covered in the literature on teaching foreign languages to people with disabilities [5-7], which deals with the possibility of using technical means of training [8] and the Internet [9], the peculiarities of the educational process adaptation [10], inclusion strategies and foreign language teaching technology to this category of students [11]. It should be particularly 
noted that some authors do not refuse to use tactile manuals written in Braille, especially for the study of vocabulary and grammar [12], and offer a methodological model of teaching foreign language for students with special educational needs [13].

A characteristic feature of blind students is that they use mainly the auditory and tactile channels to receive information. The development of modern technologies has led to the fact that previously popular printed manuals are gradually giving way to audio fragments that can be listened to and recorded independently using relatively inexpensive mobile devices. Blind students are relatively free to control computer devices, using special operating systems that voice all user actions. Analysis of publications on the problems of teaching blind students [14] allowed focusing on audio-lingual, grammatical-translation, and communicative methods as the main approach to learning a foreign language by this category of learners.

In 2016-2017, a creative group of teachers and students of the faculty of foreign languages of Kursk State University together with colleagues from Mount Union College (Ohio, USA) developed and recorded an audio course for the blind and visually impaired entitled "Sing and Learn English" [15], which included 40 authorial audio lessons, each lasting 40-60 minutes. The developed lessons are based on a number of grammar-related songs, whose lexical and grammatical structures are explained in detail and consolidated in exercises. Audio recordings contain answers for independent mastering of learning material. To increase motivation, the lessons include dialogues and interviews, crosscultural information, quizzes, and conversational games.

In the 2017-2018 and 2018-2019 academic years, the faculty of foreign languages of the Kursk State University conducted preparatory language courses for five students of the faculty of arts, three totally blind, and two visually impaired. Classes were held twice a week for 90 minutes. The initial level of English proficiency of participants in this project was characterized as "beginners". Students of the faculty of foreign languages participated in the courses as volunteer tutors, which undoubtedly represented an important aspect of professional advancement for future teachers of inclusive education.

During the 2019-2020 academic years, work continued towards the implementation of inclusive education. Two totally blind participants were involved in trial training in a group of students of the faculty of foreign languages who studied English as a second foreign language. Participation in various conferences and additional individual classes enabled them to reach a high enough language level to plan their master's studies and get the qualification of an English language teacher. It was particularly difficult for teachers to teach the reading and writing skills of such students. However, the experience of trial training has shown that almost any task can be adapted for the blind. Inclusion allowed other students of the group to take a different look at people with disabilities and gain invaluable experience for the upcoming teaching practice.

In the course of conducting inclusive classes, adaptive didactic materials are constantly developed, in particular, based on simplified editions of English-language fiction. In collaboration with teachers of the Moscow City University, a series of video lessons and methodological lectures on inclusion [16] is being created and posted in the public domain.

\section{Promising areas for further research}

In the framework of the project, teaching English to visually impaired students of secondary school No. 57 in Kursk has been started to attract their interest in learning a foreign language, and make it possible for blind students to try themselves as teachers and, taking into account their experience, help children overcome challenges in learning. The quarantine measures enforced in the spring of 2020 did not allow this work to be fully implemented, but they raised the problem of the need to create didactic materials for 
distance learning. In this regard, the use of modern computer typhlotechnologies for the development, among other things, of writing skills in blind students is considered promising. For example, the voice input feature available in Google Docs allows dictating text, edit it, insert lists, navigate through text, and format it without touching the keyboard (https://youtu.be/v0rPu_pl0D8).

The possibility of using video materials based on typhlocommenting for blind students is attractive as well.

The second approach involves deepening the methodological training of blind students to develop the English language lessons based on audio materials. To achieve this goal, it is planned to organize classes where all students, both sighted and blind, will be able to try themselves as English teachers to address challenges and overcome possible psychological barriers associated with the need to manage a group of students, monitor the performance of tasks, correct mistakes, and lead a discussion.

\section{Discussion}

The results of the study, based on theoretical analysis, trial training, pedagogical observation, and interviewing participants in the inclusive educational process, are reflected in 11 publications, contributions presented at five international conferences, including the Conference of the Association for Education and Rehabilitation of the Blind and Visually Impaired, held in Reno (Nevada, USA) in 2018, six national and regional conferences, the 8th All-Russian Science Festival SCIENCE 0+, as well as at seminars and masterclasses. Participants of the discussion note the importance of developing foreign language education for people with disabilities in an inclusive format, positively assess the methodological experience accumulated in the course of study, and share the developed didactic materials. Foreign colleagues note a fairly good level of the English language proficiency and high motivation to teach blind students at the faculty of foreign languages.

\section{Conclusion}

The results of study conducted at the Kursk State University aimed at revealing the possibilities of teaching foreign languages to blind and visually impaired students in the format of inclusive education have allowed drawing the following conclusions.

- Mastering foreign languages by blind students at the university is possible and effective when using the developed adaptive techniques and learning materials, high intrinsic motivation of persons with visual disabilities, as well as the availability of an affordable and comfortable environment.

- The described form of work enables people with visual disabilities to give credence to their abilities, better adapt to modern living, and open up prospects for self-actualization in professional activities.

- Involving teachers and students in the preparation of teaching materials and conducting classes in an inclusive environment promotes the professional and personal advancement of all participants of the educational process, impelling the desire to voluntary work and participation in creative projects.

- The development of inclusive education is an excellent basis for the international cooperation of teachers and students.

All the above confirms once again the importance of the contribution of inclusive education to improving the living quality of people, since, in the course of education, socialization, and adaptation in society, not only children [17, p. 127] but also people with special needs of all ages actively interact with those around them. 


\section{References}

1. World Health Organization, WHO launches first World report on vision (Official website of the World Health Organization, Geneve, 2019). Accessed on: December 20, 2020. [Online]. Available: https://www.who.int/ru/news-room/detail/08-10-2019-wholaunches-first-world-report-on-vision.

2. Ministerio de Educación y Ciencia, The Salamanca Statement and Framework for Action on Special Needs Education adopted by the World Conference on Special Needs Education: Access and Quality, Salamanca, Spain, 7-10 June 1994 (UNESDOC, Paris, 1994). Accessed on: December 20, 2020. [Online]. Available: https://unesdoc.unesco.org/ark:/48223/pf0000098427

3. D. Mitchell, Effektivnyye pedagogicheskiye tekhnologii spetsial'nogo i inklyuzivnogo obrazovaniya [Effective pedagogical technologies of special and inclusive education] (Publishing house of Russian Disability NGO Perspektiva, Moscow, 2011). Accessed on: December 20, 2020. [Online]. Available: http://centerprof38.ru/sites/default/files/one_click/mitchel_tehnologii.pdf

4. T.S. Makarova, Inklyuzivnoye inoyazychnoye obrazovaniye: situativnyye metody formirovaniya metodicheskoy kompetentsii uchitelya inostrannogo yazyka [Inclusive foreign language education: situational methods of forming the methodological competence of a foreign language teacher], in Topical issues of modern linguistics (Materials of the 4th All-Russian scientific and practical conference dedicated to the 85th anniversary of MRSU and the 70th anniversary of ILIC), 94-99 (Moscow State Regional University, Moscow, 2017)

5. S. Christidou, US-China Foreign Language, 14(3), 214-226 (2016). https://doi.org/10.17265/1539-8080/2016.03.005

6. T. K. Arslantaş, IHEAD: Ihlara Journal of Educational Research, 2, 95-104 (2017). Accessed on: December 20, 2020. [Online]. Available: https://dergipark.org.tr/tr/pub/ihead/issue/33690/373505

7. A. Fansury, N. Lutfin, S. Arsyad, Klasikal: Journal of Education, Language Teaching and Science, 1(1), 1-9 (2019). https://doi.org/10.31219/osf.io/8r2m3

8. D.G. Enjelvin, Journal of Further and Higher Education, 33(3) (2009). https://doi.org/10.1080/03098770903026180

9. O. Malinovská, L. Ludíková, Procedia - Social and Behavioral Sciences, 237, 311-318 (2017). https://doi.org/10.1016/J.SBSPRO.2017.02.096

10. S. Susanto, D. S. Nanda, English Review Journal of English Education, 7(1), 83 (2018). https://doi.org/10.25134/erjee.v7i1.1530

11. A.P. Lintangsari, I. Emaliana, International Journal of Evaluation and Research in Education, 9(2), 439-447 (2020). https://doi.org/10.11591/ijere.v9i2.20436

12. T.S. Makarova, M.A. Molchanova, E.A. Morozova, P.A. Stepichev, Diskussiya, 8(71), 136-140 (2016). Accessed on: December 20, 2020. [Online]. Available: https://cyberleninka.ru/article/n/teaching-english-to-bvi-learners

13. S.Yu. Umerenkov, Scientific Notes: The online academic journal of Kursk State University, 4(44), 143-149 (2017). Accessed on: December 20, 2020. [Online]. Available: https://www.elibrary.ru/item.asp?id=30731815

14. N.A. Lankina, Ye.B. Ulkina, Learn to understand the blind: guidance manual (Amur regional special library for the blind and visually impaired, Blagoveshchensk, 2011)

15. V.V. Klimentyeva, S.Yu. Umerenkov, D.D. Klimentyev, "Sing and Learn English" Audiolingual English Language Course for Blind and Visually Impaired Learners 
(Kursk State University, Kursk, 2017). Accessed on: December 20, 2020. [Online]. Available: https://cloud.mail.ru/public/KEhb/qJB8hGsZi

16. Teaching English as a Foreign Language to Blind and Visually Impaired Learners. Educational web-site created in cooperation by Moscow City University and Kursk State University. Accessed on: December 20, 2020. [Online]. Available:

https://sites.google.com/view/englishforbvistudents/\%D0\%B3\%D0\%BB $\% \mathrm{D} 0 \% \mathrm{~B} 0 \% \mathrm{D}$ $0 \% \mathrm{~B} 2 \% \mathrm{D} 0 \% \mathrm{BD} \% \mathrm{D} 0 \% \mathrm{~B} 0 \% \mathrm{D} 1 \% 8 \mathrm{~F}$ ?authuser=1.

17. T.S. Makarova, M.A. Molchanova, Ye.A. Morozova, S.G. Staritsyna, Diskussiya, 1(75), 126-132 (2017). Accessed on: December 20, 2020. [Online]. Available: https://cyberleninka.ru/article/n/individualnyy-obrazovatelnyy-marshrut-kak-uslovierealizatsii-inklyuzivnogo-inoyazychnogo-obrazovaniya 